\title{
Interplay of multiple goods, ecosystem services, and property rights in large social-ecological marine protected areas
}

\author{
$\underline{\text { Natalie C. Ban }}^{1,2}$, Louisa S. Evans ${ }^{2,3}$ Mateja Nenadovic $^{4}$ and Michael Schoon $^{5}$
}

\begin{abstract}
Protected areas are a cornerstone of biodiversity conservation, and increasingly, conservation science is integrating ecological and social considerations in park management. Indeed, both social and ecological factors need to be considered to understand processes that lead to changes in environmental conditions. Here, we use a social-ecological systems lens to examine changes in governance through time in an extensive regional protected area network, the Great Barrier Reef Marine Park. We studied the peerreviewed and nonpeer-reviewed literature to develop an understanding of governance of the Great Barrier Reef Marine Park and its management changes through time. In particular, we examined how interacting and changing property rights, as designated by the evolving marine protected area network and other institutional changes (e.g., fisheries management), defined multiple goods and ecosystem services and altered who could benefit from them. The rezoning of the Great Barrier Reef Marine Park in 2004 substantially altered the types and distribution of property rights and associated benefits from ecosystem goods and services. Initially, commonpool resources were enjoyed as common and private benefits at the expense of public goods (overexploited fisheries and reduced biodiversity and ecosystem health). The rezoning redefined the available goods and benefits and who could benefit, prioritizing public goods and benefits (i.e., biodiversity conservation), and inducing private costs (through reduced fishing). We also found that the original conceptualization of the step-wise progression of property rights from user to owner oversimplifies property rights based on its division into operational and collective-choice rule-making levels. Instead, we suggest that a diversity of available management tools implemented simultaneously can result in interactions that are seldom fully captured by the original conceptualization of the bundling of property rights. Understanding the complexities associated with overlapping property rights and multiple goods and ecosystem services, particularly within large-scale systems, can help elucidate the source and nature of some of the governance challenges that large protected areas are facing.
\end{abstract}

Key Words: ecosystem services; Great Barrier Reef; marine conservation; marine protected area; property rights; social-ecological systems

\section{INTRODUCTION}

Fisheries declines and marine biodiversity loss are ongoing environmental issues, with major repercussions for humanity and an urgent need for solutions (Worm et al. 2006, Cardinale et al. 2012, Costello et al. 2012). Two key tools are advocated to alleviate these problems. First, marine protected areas (MPAs) form a cornerstone of biodiversity conservation, with implementation increasing rapidly over the last three decades (Toropova et al. 2010, Marton-Lefèvre 2014). MPAs range in levels of protection, often incorporating multiple types of zones, spanning from general use zones to no-take or no-entry areas (Day et al. 2012). While no-take areas in particular have been shown to have positive effects on fish biomass and species richness and to contribute to ecosystem stability (Williamson et al. 2004, Lester et al. 2009), their effects on resource-dependent communities are less clear (Christie et al. 2003).

Second, improved definitions of property rights are increasingly advocated to improve fisheries sustainability (Yandle 2006, Allison et al. 2012, Vincent and Harris 2014). Industrial fisheries with rights-based fisheries reforms, referred to as catch shares or dedicated access fisheries in which fishers are allocated individual or community rights rather than industry-wide quotas, have been shown to be more sustainable than fisheries without such mechanisms (Costello et al. 2008). Indeed, externalities pose a big challenge in sustainability and could be ameliorated through property rights (Kinzig et al. 2013). Many nongovernmental organizations and funders are now advocating for better defining property rights in the oceans (e.g., http://www.fishforever.org/), making this an active area of research and implementation; the focus has been on environmental and economic gains rather than on evaluating broader impacts (Allison et al. 2012).

Both of these approaches to reducing fisheries and marine biodiversity declines recognize that marine systems are interlinked social and ecological systems. More attention to date has focused on studying ecological rather than social outcomes of MPAs and rights-based fisheries approaches (e.g., improvements in density and biomass of marine flora and fauna inside vs. outside MPAs and in fisheries that use catch shares). Increasingly, studies are also investigating social benefits and costs (Cinner 2007, Pinkerton and Edwards 2009, Mascia et al. 2010, Pollnac et al. 2010), and conservation science is focusing on integrating ecological and social aspects of MPAs in particular (Brechin et al. 2002, Christie 2004, Ban et al. 2009, Fox et al. 2012). Because social and ecological factors combine to create environmental problems and solutions, both need to be considered to understand processes that lead to changes in environmental conditions. Concepts to assist with exploring marine social-ecological systems (SESs), different types of governance effects, and who or what is affected, include ecosystem services, goods, and property rights.

Our purpose was to use the SES framework as an overarching tool to bring together literature on ecosystem services, goods, and property rights to assess the effects of governance innovation and

${ }^{1}$ School of Environmental Studies, University of Victoria, ${ }^{2}$ Australian Research Council Centre of Excellence for Coral Reef Studies, James Cook University, ${ }^{3}$ Geography, University of Exeter, ${ }^{4}$ Duke University Marine Laboratory, Duke University, ${ }^{5}$ Center for Behavior, Institutions, and the Environment, Arizona State University 
Fig. 1. Great Barrier Reef Marine Park before (A) and after (B) rezoning. Green, Marine National Park Zone (also called Green Zone; these are no-take zones); light blue, General Use Zone; turquoise, Habitat Protection Zone; yellow, Conservation Park Zone; olive, Buffer Zone; orange, Scientific Research Zone; red, Preservation Zone. Maps courtesy of the Spatial Data Centre, Great Barrier Reef Marine Park Authority, C Commonwealth of Australia (Great Barrier Reef Marine Park Authority) 2013.

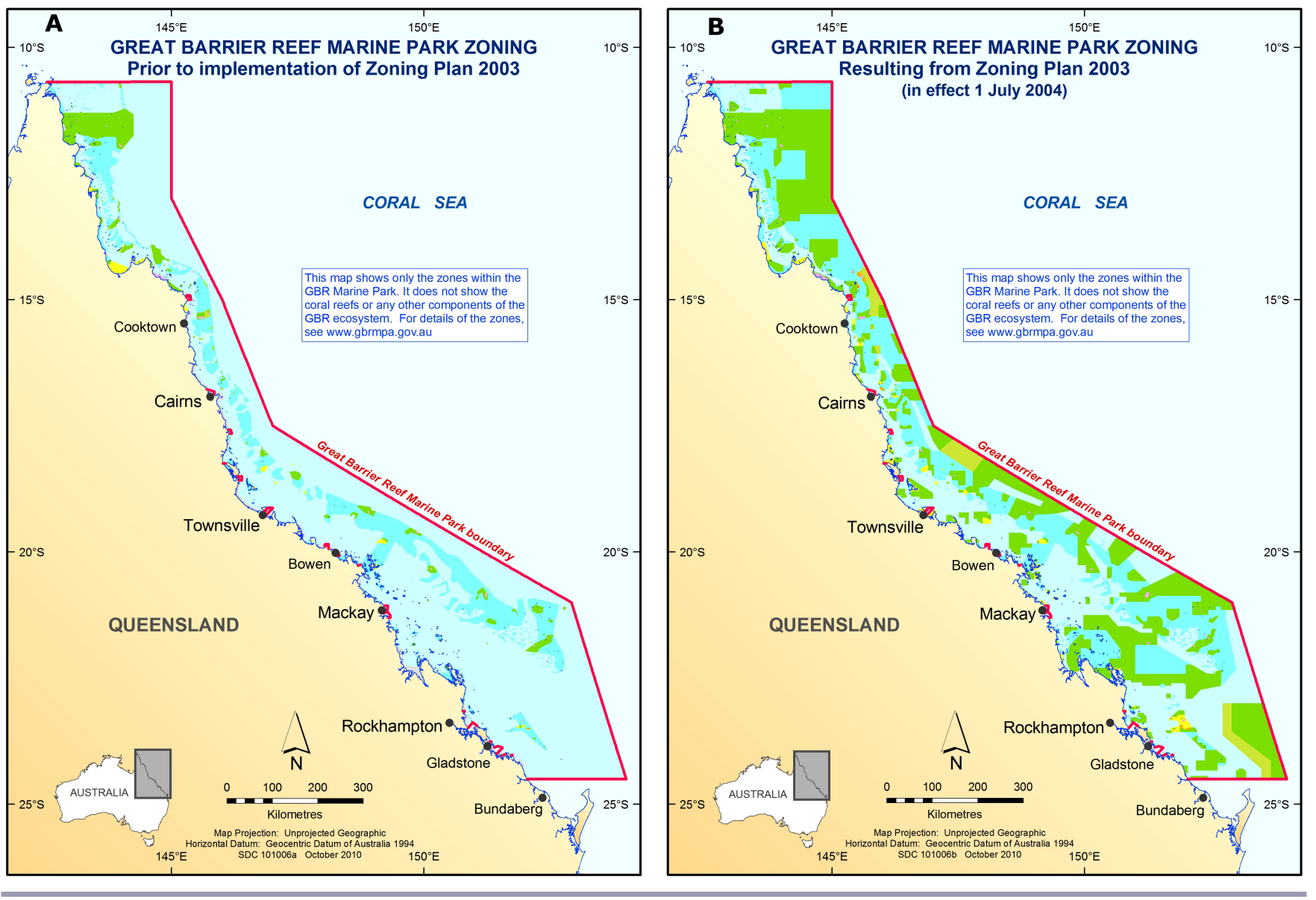

reform on varied social and ecological outcomes in an SES. Our case study is the Great Barrier Reef Marine Park (GBRMP), Australia, which undertook a major rezoning effort (e.g., no-take areas increased from $4.6 \%$ to $33 \%$, Fig. 1) that was implemented in 2004. Our case study complements another effort to examine large cases as SESs (Cox 2014). Indeed, the need for our research emerged from another assessment about changes in the Great Barrier Reef SES that did not capture the nuances of changing ecosystem services, goods, and property rights (Evans et al. 2014). MPAs, like rights-based fisheries management, work through changing property rights. In the GBRMP, rezoning changed property rights by substantially altering the spatial extent of different zones that prohibit certain uses. We are interested in the spatial change in property rights, i.e., where different activities can be carried out, but also discuss fisheries management changes. We contend that integrating concepts of goods and property rights with the interdisciplinary concept of ecosystem services better illuminates the key processes and varied outcomes of governance, including implementation of MPA networks and rights-based fisheries management. We are interested in two aspects of outcomes: how goods and ecosystem services changed, and who benefited as a result of changing property rights. We use the SES framework to structure our case study.

\section{CONCEPTS: SOCIAL-ECOLOGICAL SYSTEMS, ECOSYSTEM SERVICES, TYPES OF GOODS, AND PROPERTY RIGHTS}

The SES framework was developed to integrate social and ecological factors and their interactions, with a key goal to provide a common basis for organizing and understanding SESs (Ostrom 2007, 2009). The framework divides SESs into four core subsystems: resource system, resource units, governance system, and actors, all of which are embedded within a larger ecological, social, and political setting (McGinnis and Ostrom 2014). This framework allows researchers to compare cases in a systematic manner by identifying key components of SESs (Cox 2014, Leslie et al. 2015). For example, Basurto and Ostrom (2009) demonstrated the use of the framework to evaluate the conditions under which small-scale fisheries in the northern part of the Gulf of California, Mexico, could engage in effective resource governance and avoid tragedies of the commons. The SES framework thus provides a useful guide for investigating 
Table 1. Definitions of key components of property rights components, ecosystem services, and goods, with examples. Based on McGinnis (2011) for property rights, Millennium Ecosystem Assessment (2005) for ecosystem services, and Ostrom and Ostrom (1977) for goods.

\begin{tabular}{|c|c|c|c|c|}
\hline Concept & Component & Definition & Example & Source \\
\hline \multirow[t]{5}{*}{$\begin{array}{l}\text { Prope- } \\
\text { rty } \\
\text { rights }\end{array}$} & Access & $\begin{array}{l}\text { Right to enter a defined area and enjoy its } \\
\text { benefits without removing any resources }\end{array}$ & $\begin{array}{l}\text { Tourists snorkeling or diving on a coral reef } \\
\text { after paying an access fee }\end{array}$ & $\begin{array}{l}\text { Dixon et al. (1993), } \\
\text { Barr and Mourato } \\
\text { (2009) }\end{array}$ \\
\hline & Withdrawal & $\begin{array}{l}\text { Right to obtain specified products from a } \\
\text { resource system and remove that product } \\
\text { from the area for proscribed uses }\end{array}$ & $\begin{array}{l}\text { Fishers catching a resource for which they } \\
\text { have authorization to do so }\end{array}$ & Cinti et al. (2010) \\
\hline & Management & $\begin{array}{l}\text { Right to participate in decisions to regulate a } \\
\text { resource or make improvements in } \\
\text { infrastructure }\end{array}$ & $\begin{array}{l}\text { Fishers deciding how to distribute fishing } \\
\text { spots among themselves }\end{array}$ & Berkes (1986) \\
\hline & Exclusion & $\begin{array}{l}\text { Right to participate in the determination of } \\
\text { who has right of access, withdrawal or } \\
\text { management }\end{array}$ & $\begin{array}{l}\text { Governing body determining who can } \\
\text { participate in rule-making or who can } \\
\text { access fishing grounds }\end{array}$ & $\begin{array}{l}\text { Basurto (2005), } \\
\text { Gelcich et al. (2010) }\end{array}$ \\
\hline & Alienation & $\begin{array}{l}\text { Right to sell, lease, bequeath, or otherwise } \\
\text { transfer any of the preceding component } \\
\text { rights }\end{array}$ & $\begin{array}{l}\text { Fishers transferring some or all of their } \\
\text { withdrawal rights to other individuals }\end{array}$ & $\begin{array}{l}\text { Eythórsson (2000), } \\
\text { Carothers and } \\
\text { Chambers (2012) }\end{array}$ \\
\hline \multirow{4}{*}{$\begin{array}{l}\text { Ecosy- } \\
\text { stem } \\
\text { services }\end{array}$} & Provisioning services & Products obtained from ecosystems & $\begin{array}{l}\text { Commercial and recreational fisheries catch } \\
\text { fish for consumption }\end{array}$ & $\begin{array}{l}\text { Deloitte Access } \\
\text { Economics (2013) }\end{array}$ \\
\hline & Cultural services & $\begin{array}{l}\text { Nonmaterial benefits people get from } \\
\text { ecosystems through enjoyment, spiritual } \\
\text { enrichment, recreation, etc. }\end{array}$ & $\begin{array}{l}\text { Tourism, commercial and recreational } \\
\text { fishing, and research are examples and } \\
\text { contributed AU } \$ 6.9 \text { billion in } 2006-2007 \\
\text { and AU } \$ 5.7 \text { billion in 2011-2012 to the } \\
\text { Australian economy }\end{array}$ & $\begin{array}{l}\text { Deloitte Access } \\
\text { Economics (2013), } \\
\text { http://www.gbrmpa. } \\
\text { gov.au/zoning- } \\
\text { permits-and-plans/ } \\
\text { environmental- } \\
\text { management-charge }\end{array}$ \\
\hline & Regulating services & $\begin{array}{l}\text { Benefits obtained from regulation of } \\
\text { ecosystem processes }\end{array}$ & $\begin{array}{l}\text { Key regulating services provided by the } \\
\text { Great Barrier Reef Marine Park include } \\
\text { protection from storms and tsunamis, water } \\
\text { purification, climate regulation, and carbon } \\
\text { sequestration }\end{array}$ & Stoeckl et al. (2011) \\
\hline & Supporting services & $\begin{array}{l}\text { Services necessary for the production of } \\
\text { other ecosystem services }\end{array}$ & $\begin{array}{l}\text { Key supporting services include nutrient } \\
\text { cycling, habitat provision, coastal } \\
\text { protection, and ecosystem resilience }\end{array}$ & Stoeckl et al. (2011) \\
\hline \multirow[t]{4}{*}{ Goods } & Public goods & $\begin{array}{l}\text { A tangible commodity or product that can be } \\
\text { accessed and enjoyed by everyone without } \\
\text { subtracting from the enjoyment of others }\end{array}$ & Clean water, biodiversity & Stoeckl et al. (2011) \\
\hline & Private goods & $\begin{array}{l}\text { A tangible commodity or product that is } \\
\text { consumed by one or a few individuals and } \\
\text { hence is not available to others }\end{array}$ & $\begin{array}{l}\text { Boats, fuel, fishing gear, harvested seafood, } \\
\text { individual transferable (tradeable) quota }\end{array}$ & \\
\hline & Toll goods & $\begin{array}{l}\text { A tangible commodity or product for which } \\
\text { access is restricted, yet use by one does not } \\
\text { subtract from the enjoyment of others }\end{array}$ & Tourist charter boats, ecological research & $\begin{array}{l}\text { http://www.gbrmpa. } \\
\text { gov.au }\end{array}$ \\
\hline & $\begin{array}{l}\text { Common-pool } \\
\text { resources }\end{array}$ & $\begin{array}{l}\text { A tangible commodity or product that can be } \\
\text { relatively easily accessed but once harvested } \\
\text { or consumed is not available to others }\end{array}$ & Numerous fisheries & Ostrom (1990) \\
\hline
\end{tabular}

environmental issues and solutions for which both social and ecological characteristics matter. We used the SES framework to identify key components (resources, actor groups, governance system) that matter at the scale of our case and examined how these components were affected by the rezoning.

To complement the SES framework, we employed interdisciplinary concepts of ecosystem goods and services for our analysis. Ecosystem services refer to the benefits that people derive from nature. Ecosystem services are commonly categorized into provisioning, cultural, regulating, and supporting services (see Table 1 for definitions; Millennium Ecosystem Assessment 2005). Different ecosystem services behave like specific types of goods, i.e., public, private, common-pool resources, or toll goods, depending on the service, its purpose of use, and the property rights assigned to it, all of which determine levels of exclusivity and subtractability (Table 1, Fig. 2; Ostrom and Ostrom 1977). We refer to goods in the economic sense as tangible commodities such as products, materials, or services. Exclusivity occurs when users can be denied goods unless they meet the conditions of the supplier or owner (i.e., they can easily be denied access to goods). Subtractability implies that a good used by one cannot be used by others (Ostrom and Ostrom 1977). Importantly, goods are not synonymous with property rights but can be governed using different rights arrangements. 
Fig. 2. Examples of activities and ecosystem services derived from different types of goods and ecosystem services in the Great Barrier Reef Marine Park. Black text, types of goods; purple text, ecosystem services; orange text, examples. Types of goods are delineated into four categories here but should be viewed as a continuum.

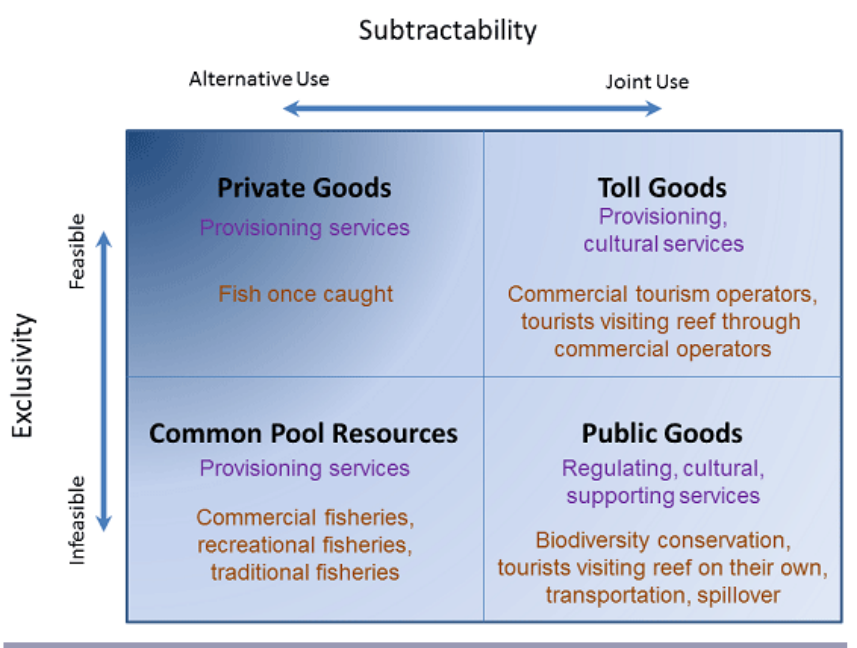

Property rights are a key management tool used to assign benefits from ecosystems to people (Table 1). Although the details of property rights vary from place to place with beliefs, conventions, and legal and institutional context (Baland and Platteau 1996, McCay 1996, 2002), the components of these rights appear to be consistent and stable (Schlager and Ostrom 1992). In marine systems, relevant components of property rights include rights of access (ability to visit an area), withdrawal (take specific products), management or comanagement (participate in decisions about management), exclusion (determine who is excluded from a right of access, withdrawal, or management), and alienation (sell, lease, or transfer rights; see Table 1 for full definitions and examples; Ostrom 2003, McGinnis 2011). Past research on property rights finds that such rights occur as bundles and argues that they often come as hierarchical bundles where, for example, those with management rights will also have access and withdrawal rights (Schlager and Ostrom 1992). From this perspective, the packaging of property rights advances in a simple step-progression from authorized user (right to access/withdraw resources) to claimant (adding management privileges/ responsibilities) to proprietor (adding the right of exclusion) and finally to owner (with the right of alienation). In addition, these bundles also depend on the nature of the rule-making process within which they occur: who implements the rules (operational level) and who has the authority to change or create rules (collective-choice level). In this context, the rights of access and withdrawal are at the operational level, whereas management, exclusion, and alienation are at the collective-choice level.

Since the mid-1980s, natural resource management has focused primarily on understanding how property rights and other institutions can govern common-pool resources. However, MPAs, as a particular arrangement of property rights, can deliver a range of different types of goods and thus can affect diverse ecosystem services. By merging these three distinct theoretical concepts, we can better understand how property rights that are influenced by MPA zoning specifically mediate the benefits that different stakeholders can gain from ecosystem services (Daw et al. 2011).

\section{METHODS}

\section{Case study background}

The Great Barrier Reef of Australia is a globally important marine ecosystem with vast environmental, cultural, social, and economic value. Human impacts on the Great Barrier Reef have occurred since the late 1800 s through agricultural expansion and the introduction of mining (McCulloch et al. 2003). Concern about effects on the reef in the 1960s and 1970s culminated in the Great Barrier Reef Act in 1975. In recognition of the need for improved protection for biodiversity, the GBRMP was rezoned in 2004. The rezoning substantially changed the key management tool, the zoning plan (which has seven zones), considerably increasing no-take areas from 4.6 to $33 \%$ to improve biodiversity conservation (Fig. 1). The GBRMP covers approximately 345,000 $\mathrm{km}^{2}$ and includes: islands ( $\left.1 \%\right)$; coral reefs (7\%); seagrass, shoals, and sandy or muddy seabed (61\%); continental slope (15\%); and deep ocean (16\%; GBRMPA 2009). We selected the GBRMP for our analysis because it is a large SES that provides multiple ecosystem services and underwent significant changes to its governance system, and the accompanying set of property rights, between 2004 and 2014. There is a wealth of secondary data on the GBRMP, and yet relatively few analyses of these data are informed by institutional or governance theory. Finally, the GBRMP is often given as an example of successful marine conservation but provides an interesting case of the use of property rights to achieve a broad suite of governance goals (Fernandes et al. 2005, McCook et al. 2010, Day and Dobbs 2013).

\section{Data collection and analysis}

We take a longitudinal, qualitative, case study approach (Yin 1984) to examine in-depth the multiple processes of governance transition, in particular rezoning in the GBRMP. We used the SES framework to structure the analysis by identifying key components (resources, actor groups, governance system) that matter at the scale of our case for investigating shifts in property rights, goods, and ecosystem services in the GBRMP (Fig. 3). Our analysis applies the theoretical concepts described previously to a detailed examination of change processes in the Great Barrier Reef established from the peer-reviewed and nonpeer-reviewed literature and our personal knowledge of the Great Barrier Reef SES. Using the SES framework and the integrated concepts described, our analysis pieces together a somewhat disjointed set of literature on change processes and outcomes in the Great Barrier Reef, for instance, bringing together the social and ecological, commercial and recreational, and conservation and fisheries management literature. Our analysis is somewhat limited by our reliance on available secondary data. However, we believe that despite these limitations, the ability to conduct a systematic analysis over a relatively long temporal scale $(\sim 30 \mathrm{yr})$ provides a unique opportunity to assess how goods and ecosystem services changed, and who benefited as a result of changing property rights within the SES.

Following the terminology of the SES framework, we identified the key components comprising the GBRMP as a SES (Fig. 3). 
Fig. 3. Key components of the social-ecological system framework included in this study. Based on McGinnis (2011), Basurto (2013), and McGinnis and Ostrom (2014).

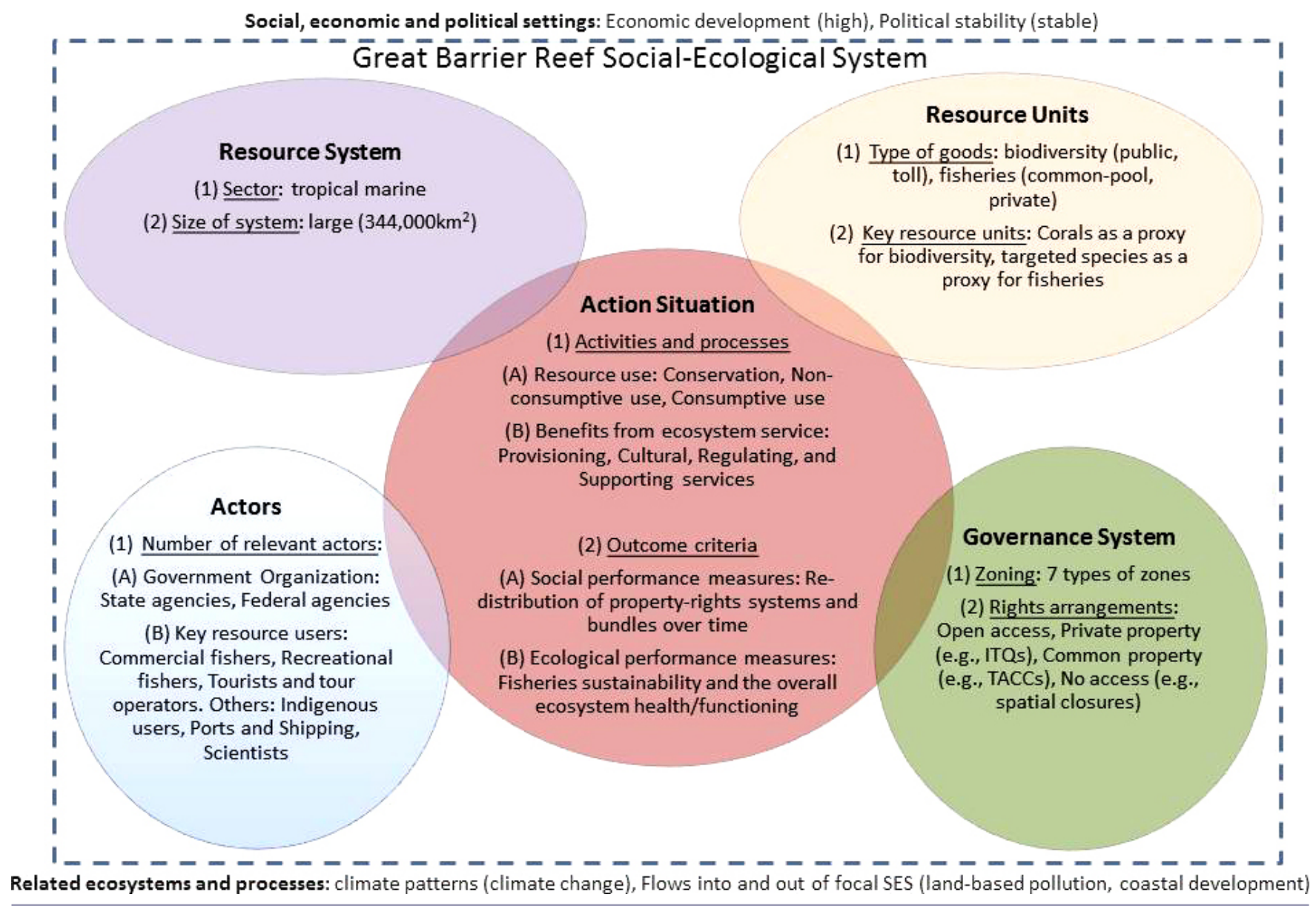

We focused on the Great Barrier Reef Marine Park Act as the governance system. We defined key actor groups as those having an effect at the scale of the GBRMP. These actors include managers of the area (reef managers and fisheries managers) and three types of users (commercial fishers, recreational fishers, and tourists). Our analysis focused on these key actor groups, as well as gear-type subgroups for commercial fisheries, because they have strong effects on the broad GBRMP system, i.e., all ecosystems contained within the park, including coral reefs, mangroves, sandy bottom, etc. (hereafter referred to as Reef). However, we recognize that there are other actors within this SES who interact in different ways with one another or with the system (e.g., farmers and other land owners in the region, environmental activists, shipping industry) and whom we did not include because of the paucity of data in regard to our research question. Governance outcomes in the GBRMP have typically been understood in terms of changes to resource units such as coral cover and target fish populations (GBRMPA 2009, 2014). In a previous analysis, we used these variables as proxies for ecosystem health and fisheries sustainability, respectively (Evans et al. 2014). For the purposes of this analysis, however, the interaction outcome variables we are interested in are: type of rights, and degree of access the rights convey to ecosystem goods and services for different actor groups. We concentrate our results on these indicative social outcomes, but, following the SES approach, we discuss them in a system-level understanding of environmental outcomes.

We synthesized key events in the management of the GBRMP over a 40 -yr period by reviewing relevant policies, legislation, and management plans (e.g., acts, zoning plans, management plans), and the peer-reviewed and nonpeer-reviewed literature. We developed a timeline of key events in the history of the GBRMP. For each key event, we deduced how property rights changed with management changes for key components of the SES, the effect these changes had on goods and ecosystem services, and who benefited. We subdivided the timeline into three periods based around major changes in the governance regime and categorized key characteristics of (and changes to) the ecosystem services and property rights systems. Furthermore, for each period, we evaluated the extent of spatial changes in management (i.e., zoning). In particular, we examined the property rights associated with each of the seven types of zones, and the corresponding goods and ecosystem services. We assessed whether the key actor groups' property rights changed between the initial zoning plan and the rezoned system. We did this by calculating the percent change in each zoning area pre- and post-rezoning. 
Table 2. Major management changes through time for the Great Barrier Reef Marine Park, and resulting property rights changes: park establishment, 1975 to 1999.

\begin{tabular}{|c|c|c|c|c|}
\hline Date & $\begin{array}{l}\text { Management event or } \\
\text { change }\end{array}$ & Resulting change in property rights & $\begin{array}{l}\text { Types of goods and ecosystem services } \\
\text { affected }\end{array}$ & $\begin{array}{l}\text { SES component } \\
\text { changed or } \\
\text { affected } \dagger\end{array}$ \\
\hline $\begin{array}{l}\text { Pre-- } \\
1975\end{array}$ & $\begin{array}{l}\text { Traditional fisheries } \\
\text { management }\end{array}$ & N/A & N/A & N/A \\
\hline 1975 & $\begin{array}{l}\text { Great Barrier Reef } \\
\text { Marine Park Act } \\
\text { passed }\end{array}$ & $\begin{array}{l}\text { Management, exclusion, and some alienation } \\
\text { rights designated to the Great Barrier Reef } \\
\text { Marine Park Authority; all access and extraction } \\
\text { rights for mining removed }\end{array}$ & $\begin{array}{l}\text { Provisioning: mining ban within park } \\
\text { boundaries prohibits extraction of all } \\
\text { mineral resources as private goods; } \\
\text { Cultural: establishment of a permitting } \\
\text { system for tourism operators that provide } \\
\text { snorkelling and diving activities as toll } \\
\text { goods }\end{array}$ & $\mathrm{G} \rightarrow \underset{\mathrm{R}}{\mathrm{A}_{\mathrm{M}}} \rightarrow \mathrm{A}_{\mathrm{U}} \rightarrow$ \\
\hline 1979 & $\begin{array}{l}\text { Comanagement } \\
\text { agreement signed } \\
\text { between federal and } \\
\text { state governments }\end{array}$ & $\begin{array}{l}\text { Management rights designated to the state } \\
\text { government }\end{array}$ & N/A & $\mathrm{A}_{\mathrm{M}} \leftrightarrow \mathrm{A}_{\mathrm{M}}$ \\
\hline $\begin{array}{l}1981- \\
1988\end{array}$ & $\begin{array}{l}\text { Initial zoning } \\
\text { implemented }\end{array}$ & $\begin{array}{l}\text { Access rights for all actors except permitted } \\
\text { scientists removed in no-entry zones; extraction } \\
\text { rights for fishers removed in no-take zones }\end{array}$ & $\begin{array}{l}\text { Provisioning: most other property rights } \\
\text { changes apply to fisheries and other } \\
\text { marine resources as common-pool } \\
\text { resources; } \\
\text { Supporting: biodiversity protection } \\
\text { through the implementation of no-take } \\
\text { zones as a public good }\end{array}$ & $\mathrm{A}_{\mathrm{M}} \rightarrow \mathrm{A}_{\mathrm{U}} \rightarrow \mathrm{R}$ \\
\hline 1981 & $\begin{array}{l}\text { Great Barrier Reef } \\
\text { World Heritage Area } \\
\text { established }\end{array}$ & $\begin{array}{l}\text { UNESCO World Heritage Committee does not } \\
\text { have authority to alter property rights but world } \\
\text { heritage status can be retracted, thereby } \\
\text { incentivising protection of the region's valued } \\
\text { ecological and cultural features }\end{array}$ & $\begin{array}{l}\text { Cultural: Adds value to the public and toll } \\
\text { goods of the Great Barrier Reef by } \\
\text { attracting national and international } \\
\text { tourists }\end{array}$ & N/A \\
\hline $\begin{array}{l}1992- \\
1993\end{array}$ & $\begin{array}{l}\text { Aboriginal native title } \\
\text { recognized }\end{array}$ & $\begin{array}{l}\text { Some access and extraction rights re-established } \\
\text { for indigenous groups on land }\end{array}$ & N/A & N/A \\
\hline 1994 & Fisheries Act passed & $\begin{array}{l}\text { Designated management rights in multiuse zones } \\
\text { to the Queensland Fisheries Department }\end{array}$ & N/A & $\mathrm{G} \rightarrow \underset{\mathrm{R}}{\mathrm{A}_{\mathrm{M}}} \rightarrow \mathrm{A}_{\mathrm{U}} \rightarrow$ \\
\hline
\end{tabular}

\section{RESULTS}

\section{Summary of management changes}

The GBRMP is managed for multiple values. Core strategic goals and principles include: a diverse, resilient environment; sustainable use; enhancement of "values"; integrated management; knowledge-based, precautionary management; and an informed, involved, and committed community (GBRMPA 1994). Activities within the GBRMP are managed through spatial allocation (zoning; Fig. 1) and temporal measures (e.g., seasonal closures) of various types of property rights systems (Fig. 2). Some activities are prohibited everywhere in the GBRMP (mining and oil drilling), whereas others are permitted in clearly defined areas (fishing, tourism, and shipping) and during specific times of the year (GBRMPA 2009); many of these have been changed during the course of almost 40 years of management.

Our review of management changes in the GBRMP revealed many adjustments through time that affected property rights, types of goods, and ecosystem services. We divided management of the GBRMP into three phases: initial zoning (1975-1999; Table 2), transition period (1999-2003; Table 3), and rezoned system (2004-current; Table 4). Here, we provide a much-abbreviated summary. Spatial management of the Reef began with the creation of the marine park in 1975 and its governing authority, the Great Barrier Reef Marine Park Authority (GBRMPA). The Great Barrier Reef Marine Park Act prohibited mining throughout the region, enabled zoning to differentiate access and use rights for the park, and assigned management, exclusion, and alienation rights to the GBRMPA, authorizing it to design a system of other permissions to regulate, enforce, sanction, and monitor activities, including harvesting, shipping, and research. The initial zoning plan was prepared and gazetted in 1981 and implemented incrementally (Day 2002). The transition period occurred from 1999 to 2003-2004, when a systematic conservation planning approach called the Representative Areas Programme was undertaken. The program aimed to identify and implement a larger network of no-take zones that represented the diversity of bioregions and habitats encompassed in the GBRMP. The rezoned system saw the implementation of the new zoning plan in 2004. The plan designated seven marine zones ranging from "most reasonable use" to no-entry areas reserved for research purposes only. With the exception of the no-entry and no-take zones, access to other areas of the multiuse park are "as of right" or by permit (Macintosh et al. 2010).

Changes in management in the GBRMP affected several kinds of social-ecological interactions. Overarching interactions involve the introduction or significant amendment of the 
Table 3. Major management changes through time for the Great Barrier Reef Marine Park, and resulting property rights changes: transition period, 1999-2003.

\begin{tabular}{|c|c|c|c|c|}
\hline Date & $\begin{array}{l}\text { Management event or } \\
\text { change }\end{array}$ & Resulting change in property rights & $\begin{array}{l}\text { Types of goods and ecosystem services } \\
\text { affected }\end{array}$ & $\begin{array}{l}\text { SES component } \\
\text { changed or } \\
\text { affected } \dagger\end{array}$ \\
\hline 1999 & $\begin{array}{l}\text { Representative Areas } \\
\text { Programme commences }\end{array}$ & $\begin{array}{l}\text { Great Barrier Reef Marine Park Authority exercise } \\
\text { their management right to rezone park }\end{array}$ & N/A & $\mathrm{A}_{\mathrm{M}} \rightarrow \mathrm{A}_{\mathrm{U}} \rightarrow \mathrm{R}$ \\
\hline 2000 & $\begin{array}{l}\text { Queensland East Coast } \\
\text { Trawl Fisheries } \\
\text { Management Plan } \\
\text { implemented }\end{array}$ & $\begin{array}{l}\text { Plan followed a significant reduction in effort quota } \\
\text { and licenses allocated to the fishery; while overall } \\
\text { withdrawal rights were reduced, remaining operators } \\
\text { could buy a larger share of remaining withdrawal } \\
\text { rights, which they also have the right to lease or sell to } \\
\text { other operators (alienation rights) }\end{array}$ & $\begin{array}{l}\text { Provisioning: reduced pressure on } \\
\text { common-pool resources; } \\
\text { Supporting: possible benefits for } \\
\text { global biodiversity through sustainable } \\
\text { fisheries and reduced habitat impacts }\end{array}$ & $\mathrm{A}_{\mathrm{M}} \rightarrow \mathrm{A}_{\mathrm{U}} \rightarrow \mathrm{R}$ \\
\hline 2001 & $\begin{array}{l}\text { Croker Decision } \\
\text { extending Indigenous } \\
\text { Australian's rights to } \\
\text { Sea Country }\end{array}$ & $\begin{array}{l}\text { Some access and extraction rights re-established for } \\
\text { indigenous groups in sea-country }\end{array}$ & $\begin{array}{l}\text { Provisioning: greater rights over } \\
\text { marine common-pool resources for } \\
\text { indigenous subsistence purposes }\end{array}$ & $\mathrm{G} \rightarrow \mathrm{A}_{\mathrm{U}} \rightarrow \mathrm{R}$ \\
\hline
\end{tabular}

governance system (Governance $[\mathrm{G}] \rightarrow$ Managers $\left[\mathrm{A}_{\mathrm{M}}\right] \rightarrow$ Users $\left[\mathrm{A}_{\mathrm{U}}\right] \rightarrow$ Resources [R]; Tables 2, 3, and 4), for example, when the Great Barrier Reef Marine Park Act (1975) and Fisheries Act (1994) were passed. For instance, the Great Barrier Reef Marine Park Act prohibited all seabed mining, thus directly affecting the acquisition of private goods by a specific user group. In another instance (Croker Decision 2001), a change to the governance system directly influenced users and thereby affected the resource system $(\mathrm{G} \rightarrow$ $A_{U} \rightarrow R$ ). This decision resulted in collective-choice rights for indigenous groups who now comanage their common-pool resources. More often, collective-choice rights remained with managers who made decisions to change operational institutions within the existing governance frame, leading to changes in the property rights of users and in turn affecting the resource $\left(A_{M} \rightarrow\right.$ $A_{U} \rightarrow R$ ). This type of interaction occurred when the initial zoning was implemented (1981-1988), during the Representative Areas Programme (1999-2003), and in changes to fisheries management plans (e.g., DEEDI 2009). In these cases, management agencies restricted the property rights of users for the extraction of common-pool resources within the park. Finally, one interaction created a link between two management agencies (comanagement agreement in 1979; $A_{M} \leftrightarrow A_{M}$ ).

\section{Changes in goods, ecosystem services, and property rights}

Management changes since the implementation of the GBRMP signal a general trend of reduced provisioning services in an attempt to increase cultural, regulating, and provisioning services (i.e., reducing fishing to allow depleted species to recover and be fished again; Tables 2, 3, and 4). The GBRMP was initially established to prevent mining within the park boundaries (Table 2). With continued evidence of declining ecosystem health, including regulating and supporting services (Stoeckl et al. 2011), subsequent management changes reduced the extent and intensity of provisioning services (i.e., commercial and recreational fishing). Of the users, commercial fishers carried the highest cost and recreational fishers some cost, whereas tourists benefited. In particular, the rezoning effort reduced the area available for fishing, and revised management plans in commercial fisheries (e.g., Coral Reef Finfish Fishery, East Coast Inshore Finfish Fishery, and East Coast Trawl Fisheries) restricted withdrawal rights (Table 4). These changes were supported by structural adjustment schemes to buy back fishing rights and reduce fishing capacity in the region overall (Gunn et al. 2010). Hence, fishing effort linked to provisioning services was not simply displaced in this case

Compared to ecosystem services, changes in types of goods have been more complicated (see Fig. 2 for review of types of goods). Most of the changes that reduced the spatial extent and intensity of fishing shifted fish from being a common-pool resource to serving as a public good. This shift is due to removing withdrawal rights for fish in some places (i.e., no-take zones), thus changing the role of fish from a catchable resource to emphasizing fishes' role in rebuilding fish stocks and contributing to reef health. At the same time, some commercial fisheries management changes redefined fish as private property, rather than as common-pool resources, through implementation of individual transferable quotas (ITQs). The use of ITQs created property rights that made fish an excludable good. Management actions also created toll goods (for tourism operators) for what was previously a public good by creating exclusive rights for licensed operators to take tourists to the Reef.

Most of the changes to ecosystem services and goods were implemented through shifting property rights, especially withdrawal rights. The major shift in property rights occurred when the GBRMP was rezoned. The rezoning effort was instigated primarily to address concerns that the levels of biodiversity protection for the Great Barrier Reef were inadequate and were unlikely to ensure that the entire ecosystem remained healthy, productive, and resilient into the future (Day 2011). Implemented in 2004, the rezoning changed the spatial coverage of where activities could occur (Fig. 1; Olsson et al. 2008, McCook et al. 2010). In particular, it changed the spatial coverage of the seven types of zones. Each zone permits users to engage in different types of activity, i.e., each zone has specified property rights for users (Fig. 4). The general use zone allows all reasonable use and thus permits all types of fishing (i.e., commercial trawl, gillnet, other, and recreational fishing have withdrawal rights). This zone covered $78 \%$ of the Reef before rezoning, which was reduced to $34 \%$ after rezoning. The habitat protection zone allows 
Table 4. Major management changes through time for the Great Barrier Reef Marine Park, and resulting property rights changes: rezoned system, 2004 to current.

\begin{tabular}{|c|c|c|c|c|}
\hline Date & $\begin{array}{l}\text { Management event or } \\
\text { change }\end{array}$ & Resulting change in property rights & $\begin{array}{c}\text { Types of goods and ecosystem services } \\
\text { affected }\end{array}$ & $\begin{array}{l}\text { SES component } \\
\text { changed or } \\
\text { affected } \dagger\end{array}$ \\
\hline 2004 & $\begin{array}{l}\text { Queensland Coral Reef } \\
\text { FinFish Fishery } \\
\text { Management Plan } \\
\text { implemented }\end{array}$ & $\begin{array}{l}\text { Plan introduced common and private property } \\
\text { rights through total allowable commercial catch } \\
\text { (TACC) and individual transferable quotas (ITQ) } \\
\text { for the commercial sector; these rules restricted } \\
\text { withdrawal rights but allowed commercial } \\
\text { operators to exercise greater exclusion and } \\
\text { alienation rights over their fishery resource; } \\
\text { introduced new size and bag limits, or restricted } \\
\text { withdrawal rights, for charter, recreational, and } \\
\text { commercial sectors }\end{array}$ & $\begin{array}{l}\text { Provisioning: reduced pressure on } \\
\text { common-pool resources; shift from } \\
\text { common-pool resources to private } \\
\text { goods; } \\
\text { Supporting: possible benefits for } \\
\text { global biodiversity through } \\
\text { sustainable fisheries }\end{array}$ & $\mathrm{A}_{\mathrm{M}} \rightarrow \mathrm{A}_{\mathrm{U}} \rightarrow \mathrm{R}$ \\
\hline 2004 & $\begin{array}{l}\text { New Zoning Plan for the } \\
\text { Great Barrier Reef } \\
\text { Marine Park passed and } \\
\text { implemented; Structural } \\
\text { Adjustment Package } \\
\text { agreed }\end{array}$ & $\begin{array}{l}\text { Multiple changes to access, withdrawal, } \\
\text { management, exclusion, and alienation rights (see } \\
\text { Table 2) }\end{array}$ & $\begin{array}{l}\text { Shifted emphasis from provisioning } \\
\text { services (fisheries) to supporting, } \\
\text { regulating, and cultural services }\end{array}$ & $\mathrm{A}_{\mathrm{M}} \rightarrow \mathrm{A}_{\mathrm{U}} \rightarrow \mathrm{R}$ \\
\hline 2007 & $\begin{array}{l}\text { Amendment to the Great } \\
\text { Barrier Reef Marine Park } \\
\text { Act of } 1975\end{array}$ & $\begin{array}{l}\text { Legislated for a lock-down on zoning plans and } \\
\text { thus changes to access and withdrawal rights for a } \\
\text { minimum of } 7 \text { yr from date of establishment under } \\
\text { the premise of providing stability to businesses, } \\
\text { communities, and biological systems }\end{array}$ & $\begin{array}{l}\text { Supporting: consistent protection of } \\
\text { global biodiversity, allowing time for } \\
\text { renewal of this public good where } \\
\text { previously degraded due to fishing }\end{array}$ & N/A \\
\hline 2009 & $\begin{array}{l}\text { Queensland East Coast } \\
\text { Inshore Finfish Fishery } \\
\text { Management Plan }\end{array}$ & $\begin{array}{l}\text { Plan reduced withdrawal rights by legislating more } \\
\text { stringent controls on harvesting of sharks and grey } \\
\text { mackerel through a TACC allowance, new size and } \\
\text { bag limits, and annual seasonal closures for } \\
\text { barramundi and spawning tailor }\end{array}$ & $\begin{array}{l}\text { Provisioning: reduced pressure on } \\
\text { common-pool resources; } \\
\text { Supporting: possible benefits for } \\
\text { global biodiversity through } \\
\text { sustainable fisheries }\end{array}$ & $\mathrm{A}_{\mathrm{M}} \rightarrow \mathrm{A}_{\mathrm{U}} \rightarrow \mathrm{R}$ \\
\hline 2010 & $\begin{array}{l}\text { Queensland East Coast } \\
\text { Trawl Fisheries } \\
\text { Management Plan } \\
\text { updated }\end{array}$ & $\begin{array}{l}\text { Update tightened licensing and gear regulations for } \\
\text { the fishery in consultation with trawl fishers }\end{array}$ & $\begin{array}{l}\text { Provisioning: reduction in pressure on } \\
\text { common-pool marine resources and } \\
\text { possible benefits; } \\
\text { Supporting: possible benefits for } \\
\text { biodiversity protection through } \\
\text { reduced habitat alterations }\end{array}$ & $\mathrm{A}_{\mathrm{M}} \rightarrow \mathrm{A}_{\mathrm{U}} \rightarrow \mathrm{R}$ \\
\hline 2011 & $\begin{array}{l}\text { UNESCO report on } \\
\text { Great Barrier Reef World } \\
\text { Heritage Area }\end{array}$ & $\begin{array}{l}\text { Noted increasing threat from coastal development } \\
\text { along Queensland coast }\end{array}$ & N/A & N/A \\
\hline
\end{tabular}

some extractive uses, but prohibits trawling. The conservation park zone allows some more-limited extractive uses, and the buffer zone is a bit more restrictive. The scientific research zone allows no extractive use except some scientific sampling. The marine national park zones, also known as the Green Zone, allows no extractive activities, but access rights remain (i.e., fishing boats can transit over the area as long as they do not engage in fishing). Finally, the preservation zone is the most restrictive, also prohibiting access. The rezoning effort thus changed the access, withdrawal, and exclusion rights of actors (Fig. 4). The extent of the GBRMP protected by no-take zones (i.e., areas without consumptive withdrawal rights) increased from 4.6 to $33 \%$ (115,000 km²; Figs. 1 and 4).

Unlike withdrawal rights, management rights (Table 1, Fig. 4), which enable actors to participate in decisions about regulating the resources (Ostrom 2003), did not change for users as a result of rezoning; they only changed for managers. In the GBRMP, management is formally shared between the federal and state governments, and between reef and fisheries managers. Rezoning changed the focus of management rights allocated to managers of the region (GBRMPA, Queensland Parks and Wildlife Service, and Fisheries Queensland) from fisheries management (delivering common-pool resources as a provisioning service) toward biodiversity conservation (creating a public good and supporting services), with more monitoring and enforcement of no-take zones and the public goods derived from them. Other actor groups only have an informal say in management; they can make suggestions but do not have the authority to make management changes. Tourism operators and fishers can voluntarily contribute to management activities, for example, by monitoring and reporting coral bleaching, removing crown-of-thorns-starfish (a hyperabundant species), tracking their carbon accounts, or reporting illegal fishing. Resource users do not hold management or exclusion rights per se in that they cannot decide to what extent they and others are regulated or for what purposes (Fig. 4). There are, however, informal mechanisms of comanagement between government and other actors (e.g., see roles of partners listed by 
Fig. 4. Property rights by Great Barrier Reef Marine Park zone, with zones ordered from least restrictive to most restrictive. (A) General use zone: allows reasonable use, including extraction. (B) Habitat protection zone: allows some extractive use. (C) Conservation park zone: allows some extractive use. (D) Buffer zone: limited extractive use. (E) Scientific research: no extractive use except some scientific sampling. (F) Marine national park zones: no extractive use. A checkmark indicates the presence of a particular property right for an actor group in a zone. Percentages indicate the percent area in each zone preand post-rezoning. The preservation zone is not shown because none of the property rights apply (pre-rezoning area: $0.1 \%$; post-rezoning area: $0.2 \%$ ). Property rights did not change within zones, but the proportion allocated to different zones changed with rezoning. Withdrawal rights for fisheries are consumptive, whereas for tourism are nonconsumptive. Alienation rights for commercial fisheries are only related to being able to sell individual transferable quotas.
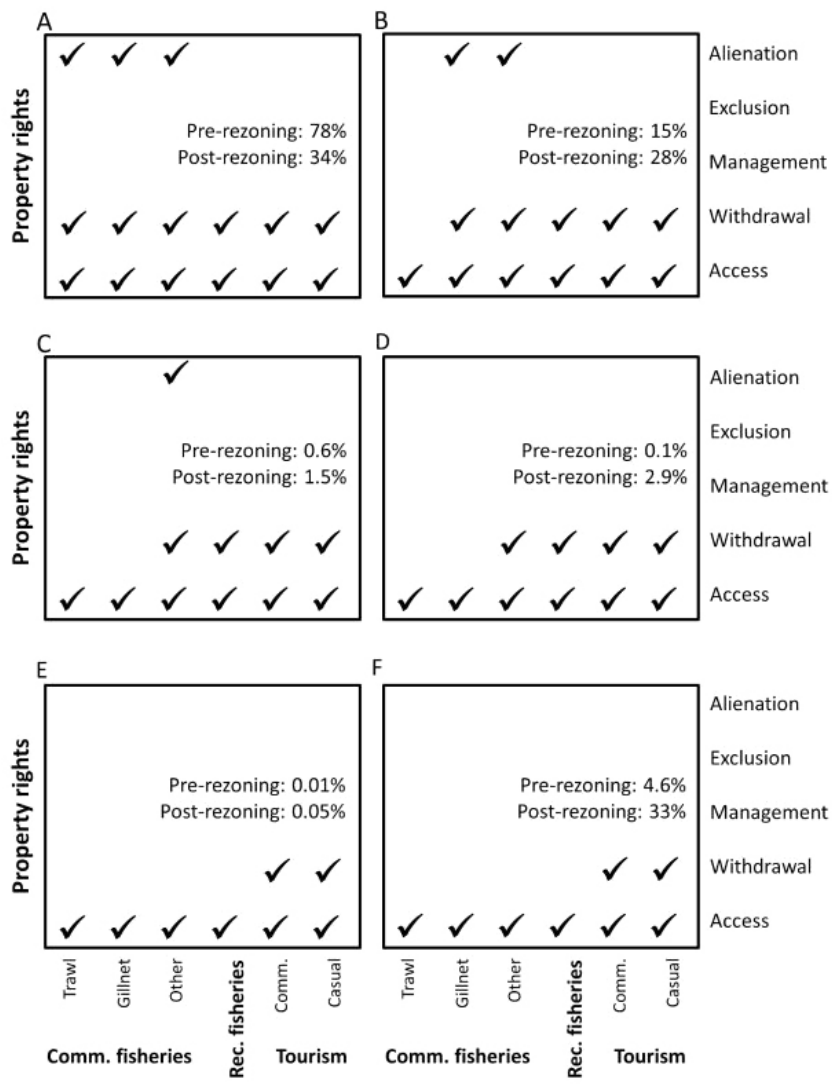

GBRMPA: http://www.gbrmpa.gov.au/our-partners). These mechanisms include stakeholder consultation during rezoning (the Great Barrier Reef Marine Park Act lays out the minimum public participation required in the preparation of a zoning plan), committees to review and update management plans and policy (e.g., Australian Government 2010), Indigenous Reef Advisory Committee and other Reef Advisory Committees, 11 Local Marine Advisory Committees, and the Reef Guardian Fishers,
Fig. 5. Changes in property rights ( $\%$ area) in the Great Barrier Reef Marine Park due to rezoning in 2004 by activity. Changes $<1 \%$ are not visible in the figure. Access rights declined by $0.1 \%$ for all activities. Withdrawal rights (nonconsumptive) declined by $0.1 \%$ for commercial and casual tourism. Management and exclusion rights did not change.

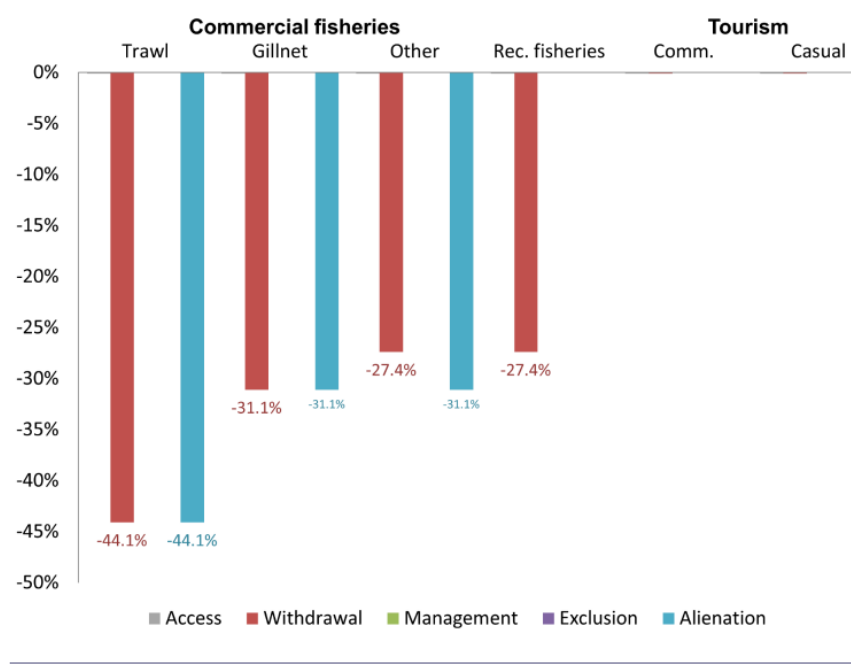

Farmers, and Councils programs. Although these diverse stakeholders and the public are consulted during development of zoning plans and other policy changes, they do not have formal management rights.

Trade-offs and changing beneficiaries

In the GBRMP, a number of trade-offs were involved when changes to management were made: trade-offs between ecosystem services and between beneficiaries of ecosystem services, often linked to types of goods and implemented through shifting property rights. Rezoning shifted the emphasis from provisioning services (fisheries) to other services (supporting, regulating, cultural). The beneficiaries of ecosystem services thus shifted as well, from those that previously relied on private and commonpool resource goods and benefited from provisioning services (fishers, traders and consumers of local fish) toward those that benefit from toll and public goods, and cultural, regulating, and supporting services. The cost of rezoning, measured as the area of property rights lost (Fig. 5), thus fell mainly onto extractive actors at a local scale, whereas the benefits accrued to those who use toll and public goods, and cultural, regulating, and supporting ecosystem services. For example, the reduction in fishable area (withdrawal rights) was $44.1 \%$ for commercial trawl fisheries, $31.1 \%$ for gillnet fisheries, and $27.4 \%$ for other fisheries (Fig. 5). Alienation rights were likewise calculated as the area that remained fishable for fisheries that are managed under tradeable quotas (i.e., fisheries that can sell, or alienate, their withdrawal rights). In contrast, there was no change in management and exclusion rights for either of the groups (Fig. 5). Benefits of protection extend beyond the local scale; thus, people who benefit from public goods and cultural, regulating, and supporting services are more widely distributed. The beneficiaries of toll goods are more local and incur some costs for the privilege (e.g., 
the cost of hiring a charter boat), although this does not compensate the extractive actors directly. For the most part, those benefiting from the Reef's public goods and ecosystem services other than provisioning services do not currently incur costs, or at least costs proportional to the benefits they receive. There is an environmental management charge for tourists visiting the reef through commercial tourism operators, but there are no other mechanisms for payments for ecosystem services currently in place for the Reef.

\section{DISCUSSION}

The major gap our work addresses is how changing property rights, resulting primarily from MPA implementation, affects the social-ecological outcomes (goods and ecosystem services) for different actors. A vast literature exists on MPAs, and a separate literature provides theoretical insights on property rights (Schlager and Ostrom 1992, Fennell 2011, Marschke et al. 2012), with as yet little connection between them (but see Mascia and Claus 2009). The link between MPAs and property rights is of particular interest to fisheries, a key use being managed within MPAs, where changes to or strengthening of property rights are actively being proposed (catch shares, Territorial User Rights Fisheries, etc.). Investigating changing property rights within an MPA, through a rezoning process, thus provides insights about the potential effects of such changes. The expanding literature on rights-based fisheries has not yet been appreciated for what it also means for marine conservation policy and planning. In the context of small-scale fisheries in developing countries, Allison et al. (2012) argue that more secure, less vulnerable fishers make better managers and stewards. They argue for an appreciation of human rights within fisheries management to bolster property rights approaches. These arguments extend to MPA implementation, in both developing and developed countries, where the effects of associated changes to property rights tend to be concentrated among one set of actors. Our study brings some of these links between rights-based fisheries outcomes and MPA governance outcomes to the foreground, in particular, the trade-offs between goods, services, and beneficiaries. Furthermore, by using the SES framework, we provide an approach for investigating how changing property rights can affect goods and ecosystem services that can be applied in other cases, allowing for future cross-case comparisons.

Our in-depth investigation of changes brought about by rezoning in the GBRMP highlight several conclusions. Management emphasis in this MPA shifted from provisioning services, i.e., allowing fishing to occur in most of the MPA, to regulating and supporting services. What were previously private benefits shifted to public goods. This was done primarily by reducing withdrawal rights to fisheries by expanding restrictive zones. The fishing method that has the most severe environmental impacts, bottom trawling (Watling and Norse 1998), also had the largest reduction in withdrawal rights. Tourists and the tourism industry are the main direct beneficiaries.

Despite some ecological benefits of the rezoning effort (i.e., demonstrated effectiveness of no-take zones at recovering depleted fish populations; McCook et al. 2010), the GBRMP still faces a number of governance challenges that emerge in part from a limited understanding of the interplay among a diverse set of property rights, goods, and ecosystem services. For instance, recreational fishing is still essentially treated as open access and so continues to manifest as uncertainty in ecological and social outcomes for Great Barrier Reef fisheries overall. Further, one challenge with the current rezoning is that where it prohibits consumptive withdrawal (fisheries) or nonconsumptive withdrawal (i.e., use by tourism), it does not necessarily prohibit access. Hence, a fishing boat may pass through a particular zone where fishing is prohibited, and it is the responsibility of management agencies to observe illegal activity directly to sanction rule-breakers. Continuing to allow unspecified access rights to zones where withdrawal rights are removed creates an added challenge in monitoring and enforcement for reef and fisheries managers, and may explain some of the disparity in ecological outcomes for no-entry and no-take zones in the Great Barrier Reef (GBRMPA 2009). Many small-scale MPAs do not allow access to fishing vessels in no-take areas. However, in largescale systems, the legitimacy of removing access to no-take zones (with implications for transport and freedom of the sea in $33 \%$ of the park) or the practicality of endeavoring to license up to 700,000 recreational fishers is a question of political debate. Nevertheless, the way in which property rights are currently allocated has continuing implications for ecological outcomes in the GBRMP.

Our analysis of changes in management of the GBRMP provides both theoretically and empirically relevant findings. In terms of theoretical findings, our case study illustrates that the mixture of property right bundles extends beyond the original classification by Schlager and Ostrom (1992), which suggests a simple stepprogression from authorized user all the way to owner. Furthermore, our case study also reveals that the original distinction among property rights components based on the rulemaking authority, i.e., operational and collective-choice levels (Schlager and Ostrom 1992), is rather rigid and cannot account for the bundling nature of property rights in the GBRMP. In this case, the right of alienation was bundled with access and withdrawal rights through ITQs and other mechanisms, akin to the authorized user privileges of the original classification. What was surprising is that management and exclusion rights were not affected by any of the modifications in the GBRMP governance system and remained out of the hands of the resource user groups. As a result, we conclude that the five-tiered step-wise progression from user to owner oversimplifies property rights with multiple types of rights. We argue that the original classification can be modified based on the specific governance system in place (i.e., top-down management, comanagement, or community-based management) and the type of implemented management tools (e.g., area closures, ITQs, trip limits, gear restrictions). In addition, we also suggest that the current management strategies that in many instances attempt to achieve multiple goals (biodiversity protection, resource conservation, enhancement) can interact with each other and, because of that, are seldom fully captured by the original classification proposed by Schlager and Ostrom (1992). Thus, the bundling of property rights takes on additional complexity and new opportunities and creates a productive area for new research opportunities.

Two aspects of our empirical findings are relevant to other regions. First, by using a large-scale case study of an evolving multiple-use MPA network, we demonstrated trade-offs in the goods and services available to actors within and across spatial 
and temporal scales: from regional to global, and before and after rezoning of the MPA. Much of the current controversy surrounding protected areas comes, in part, from the differences between beneficiaries: who pays and who profits. Governing for multiple types of goods and services results in a provision of benefits at scales, both temporal and spatial, that are different from where costs accrue. In the temporal context, conservation benefits can take decades to realize, whereas the costs of forfeiting resource use are borne in the short to medium term (Russ and Alcala 2011). However, some of the conservation benefits of the GBR rezoning occurred surprisingly quickly; for example, in the GBRMP, the recovery of coral trout was observed after 1.5 to 2 yr (Russ et al. 2008). In the spatial context, conservation benefits often occur at a regional or global scale, whereas the costs collect at a local scale. Similarly, the costs and benefits in achieving development goals such as Reef-based employment or sustainable livelihoods may not match up at a given level, but even then it is not clear that costs and benefits will cancel out or that one group at a local level will not benefit at the expense of another (Smith et al. 2010). Thus, the lens of multiple goods, ecosystem services, and property rights can provide an approach for examining crossscale linkages in SESs.

Second, our analysis indicates the importance of external drivers to the stability and proper functioning of SESs, even at the large spatial scale of GBRMP. External drivers such as land-based pollution, coastal development, climate change, and storms cannot be readily managed by MPA managers. Part of the problem, at least for regional threats and in MPAs affected by land-based effects, is that the property rights associated with goods and services on land tend to incentivize the provision of private over public goods, i.e., crops over unpolluted run-off, explaining some of the continued decline in coral cover across the Great Barrier Reef (Sweatman 2008, Hughes et al. 2011, Sweatman et al. 2011, De'ath et al. 2012). Interestingly, the threat to the GBRMP from external drivers, in particular coastal development, has caught the attention of the international community. The UNESCO World Heritage Committee has no legislative rights over the GBRMP but has threatened to list the area as "World Heritage in danger" if coastal development policy is not systematically reviewed and strategically implemented (UNESCO 2012). In effect, this committee is leveraging informal institutions and the risk of lost revenues to the Queensland Reefbased tourism industry through the reduced value of cultural services and toll goods to advocate for more stringent regulation of coastal development in the region. As with our other contributions, we found that the lens of goods, ecosystem services, and property rights can facilitate identification of external influences on MPAs.

We have built on previous approaches to integrating property rights into protected area and resource management (Schlager and Ostrom 1992, Mascia and Claus 2009), yet several limitations of our study warrant acknowledgement. Our study is based on the extensive peer-reviewed and nonpeer-reviewed literature available on management of the GBRMP but does not include new data collection. Additional insights could likely be drawn if our study could have been augmented with primary data, especially interviews with actor groups over the course of the management changes. Furthermore, while much ecological data exist about the effectiveness of zones in the GBRMP (McCook et al. 2010, Harrison et al. 2012), no equivalent social monitoring existed until recently (National Environmental Research Program 2013). Thus, we were unable to provide quantitative metrics about how actors groups have been affected or have perceived the rezoning process.

Although our case study focused on the GBRMP, similar complexities in the interplay between goods, ecosystem services, and property rights are likely evident in all large-scale, multipleuse protected areas, both terrestrial and marine. The explicit examination of these concepts and how they are applied within protected areas serves to highlight the matches and mismatches between social and ecological components of complex systems and across scales. Recognizing the inherent limitations of the provision of each type of good, and the interactions among them, and evaluating actors' incentives for the provision and use of goods and ecosystem services is crucial to effective, long-term governance of large-scale protected areas and rights-based management.

Responses to this article can be read online at: http://www.ecologyandsociety.org/issues/responses. $\mathrm{php} / 7857$

\section{Acknowledgments:}

We gratefully acknowledge input on a previous version of this manuscript by Forrest Fleischman and Graeme Cumming. We also thank Jon Day for constructive and insightful comments that much improved the manuscript. We also thank four anonymous reviewers for their suggestions, which greatly improved the paper. N. C. Ban received funding from the Social Sciences and Humanities Research Council and the Australian Research Council.

\section{LITERATURE CITED}

Allison, E. H., B. D. Ratner, B. Åsgård, R. Willmann, R. Pomeroy, and J. Kurien. 2012. Rights-based fisheries governance: from fishing rights to human rights. Fish and Fisheries 13(1):14-29. http://dx.doi.org/10.1111/j.1467-2979.2011.00405.x

Australian Government. 2010. Fisheries (East Coast Trawl) Management Plan 2010. State of Queensland, Brisbane, Australia. [online] URL: https://www.legislation.qld.gov.au/ LEGISLTN/CURRENT/F/FisherECTMP10.pdf.

Baland, J. M., and J. P. Platteau. 1996. Halting degradation of natural resources: Is there a role for rural communities? Food and Agriculture Organization, Rome, Italy.

Ban, N. C., C. R. Picard, and A. C. J. Vincent. 2009. Comparing and integrating community-based and science-based approaches in prioritizing marine areas for protection. Conservation Biology 23(4):899-910. http://dx.doi.org/10.1111/j.1523-1739.2009.01185. $\underline{\mathrm{X}}$

Barr, R. F., and S. Mourato. 2009. Investigating the potential for marine resource protection through environmental service markets: an exploratory study from La Paz, Mexico. Ocean and Coastal Management 52:568-577. http://dx.doi.org/10.1016/j. ocecoaman.2009.08.010 
Basurto, X. 2005. How locally designed access and use controls can prevent the tragedy of the commons in a Mexican small-scale fishing community. Society and Natural Resources 18:643-659. http://dx.doi.org/10.1080/08941920590959631

Basurto, X. 2013. Linking multi-level governance to local common-pool resource theory using fuzzy-set qualitative comparative analysis: insights from twenty years of biodiversity conservation in Costa Rica. Global Environmental Change 23:573-587. http://dx.doi.org/10.1016/j.gloenvcha.2013.02.011

Basurto, X., and E. Ostrom. 2009. Beyond the tragedy of the commons. Economia delle fonti di energia e dell' ambiente 26:35-60. http://dx.doi.org/10.3280/EFE2009-001004

Berkes, F. 1986. Local-level management and the commons problem: a comparative study of Turkish coastal fisheries. Marine Policy 10:215-229. http://dx.doi.org/10.1016/0308-597X(86) 90054-0

Brechin, S. R., P. R. Wilshusen, C. L. Fortwangler, and P. C. West. 2002. Beyond the square wheel: toward a more comprehensive understanding of biodiversity conservation as social and political process. Society and Natural Resources 15(1):41-64. http://dx.doi. org/10.1080/089419202317174011

Cardinale, B. J., J. E. Duffy, A. Gonzalez, D. U. Hooper, C. Perrings, P. Venail, A. Narwani, G. M. Mace, D. Tilman, D. A. Wardle, A. P. Kinzig, G. C. Daily, M. Loreau, J. B. Grace, A. Larigauderie, D. S. Srivastava, and S. Naeem. 2012. Biodiversity loss and its impact on humanity. Nature 486:59-67. http://dx.doi. org/10.1038/nature11148

Carothers, C., and C. Chambers. 2012. Fisheries privatization and the remaking of fishery systems. Environment and Society: Advances in Research 3:39-59. http://dx.doi.org/10.3167/ ares.2012.030104

Christie, P. 2004. Marine protected areas as biological successes and social failures in southeast Asia. American Fisheries Society Symposium 42:155-164.

Christie, P., B. J. McCay, M. L. Miller, C. Lowe, A. T. White, R. Stoffle, D. L. Fluharty, L. T. McManus, R. Chuenpagdee, C. Pomeroy, D. O. Suman, B. G. Blount, D. Huppert, R.-L. Willahermosa Eisma, E. Oracion, K. Lowry, and R. B. Pollnac. 2003. Towards developing a complete understanding: a social science research agenda for marine protected areas. Fisheries 28 (12):22-26.

Cinner, J. E. 2007. Designing marine reserves to reflect local socioeconomic conditions: lessons from long-enduring customary management systems. Coral Reefs 26(4):1035-1045. http://dx.doi.org/10.1007/s00338-007-0213-2

Cinti, A., W. Shaw, R. Cudney-Bueno, and M. Rojo. 2010. The unintended consequences of formal fisheries policies: social disparities and resource overuse in a major fishing community in the Gulf of California, Mexico. Marine Policy 34:328-339. http:// dx.doi.org/10.1016/j.marpol.2009.08.002

Costello, C., S. D. Gaines, and J. Lynham. 2008. Can catch shares prevent fisheries collapse? Science 321:1678-1681. http://dx.doi. org/10.1126/science. 1159478
Costello, C., D. Ovando, R. Hilborn, S. D. Gaines, O. Deschenes, and S. E. Lester. 2012. Status and solutions for the world's unassessed fisheries. Science 338:517-520. http://dx.doi. org/10.1126/science.1223389

Cox, M. 2014. Understanding large social-ecological systems: introducing the SESMAD project. International Journal of the Commons 8(2):265-276. [online] URL: http://www.thecommonsjournal. org/index.php/ijc/article/view/406.

Daw, T. M., J. E. Cinner, T. R. McClanahan, N. A. J. Graham, and S. K. Wilson. 2011. Design factors and socioeconomic variables associated with ecological responses to fishery closures in the western Indian Ocean. Coastal Management 39:412-424. http://dx.doi.org/10.1080/08920753.2011.589224

Day, J., N. Dudley, M. Hockings, G. Holmes, D. Laffoley, S. Stolton, and S. Wells 2012. Guidelines for applying the IUCN Protected Area Management Categories to marine protected areas. International Union for Conservation of Nature and Natural Resources, Gland, Switzerland. [online] URL: http:// cmsdata.iucn.org/downloads/uicn categoriesamp eng.pdf.

Day, J. C. 2002. Zoning-lessons from the Great Barrier Reef Marine Park. Ocean and Coastal Management 45(2-3):139-156. http://dx.doi.org/10.1016/s0964-5691(02)00052-2

Day, J. C. 2011. Protecting Australia's Great Barrier Reef. Solutions 2(1):56-66. [online] URL: http://www.thesolutionsjournal. com/node/846.

Day, J. C., and K. Dobbs. 2013. Effective governance of a large and complex cross-jurisdictional marine protected area: Australia's Great Barrier Reef. Marine Policy 41:14-24. http://dx. doi.org/10.1016/j.marpol.2012.12.020

De'ath, G., K. E. Fabricius, H. Sweatman, and M. Puotinen. 2012. The 27-year decline of coral cover on the Great Barrier Reef and its causes. Proceedings of the National Academy of Sciences 109 (44):17995-17999. http://dx.doi.org/10.1073/pnas.1208909109

Department of Employment, Economic Development and Innovation (DEEDI). 2009. Guidelines for commercial operators in the East Coast Finfish Fishery. Department of Employment, Economic Development and Innovation, Brisbane, Australia.

Deloitte Access Economics. 2013. Economic contribution of the Great Barrier Reef. Great Barrier Reef Marine Park Authority, Townsville, Australia. [online] URL: http://www.environment. gov.au/system/files/resources/a3ef2e3f-37fc-4c6f-ab1b-3b54ffc3f449/ files/gbr-economic-contribution.pdf.

Dixon, J. A., L. Fallon Scura, and T. van't Hof. 1993. Meeting ecological and economic goals: marine parks in the Caribbean. Ambio 22:117-125.

Evans, L. S., N. C. Ban, M. Schoon, and M. Nenadovic. 2014. Keeping the 'Great' in the Great Barrier Reef: large-scale governance of the Great Barrier Reef Marine Park. International Journal of the Commons 8(2):396-427. [online] URL: http://www. thecommonsjournal.org/index.php/ijc/article/view/405.

Eythórsson, E. 2000. A decade of ITQ-management in Icelandic fisheries: consolidation without consensus. Marine Policy 24:483-492. http://dx.doi.org/10.1016/S0308-597X(00)00021-X 
Fennell, L. A. 2011. Ostrom's Law: property rights in the commons. International Journal of the Commons 5(1):9-27. [online] URL: http://www.thecommonsjournal.org/index.php/ ijc/article/view/252.

Fernandes, L., J. Day, A. Lewis, S. Slegers, B. Kerrigan, D. Breen, D. Cameron, B. Jago, J. Hall, D. Lowe, J. Innes, J. Tanzer, V. Chadwick, L. Thompson, K. Gorman, M. Simmons, B. Barnett, K. Sampson, G. De'ath, B. Mapstone, H. Marsh, H. Possingham, I. Ball, T. Ward, K. Dobbs, J. Aumend, D. Slater, and K. Stapleton. 2005. Establishing representative no-take areas in the Great Barrier Reef: large-scale implementation of theory on marine protected areas. Conservation Biology 19(6):1733-1744. http://dx. doi.org/10.1111/j.1523-1739.2005.00302.X

Fox, H. E., M. B. Mascia, X. Basurto, A. Costa, L. Glew, D. Heinemann, L. B. Karrer, S. E. Lester, A. V. Lombana, R. S. Pomeroy, C. A. Recchia, C. M. Roberts, J. N. Sanchirico, L. PetSoede, and A. T. White. 2012. Reexamining the science of marine protected areas: linking knowledge to action. Conservation Letters 5(1):1-10. http://dx.doi.org/10.1111/j.1755-263X.2011.00207. $\underline{\mathrm{x}}$

Great Barrier Reef Marine Park Authority (GBRMPA). 1994. A 25 year strategic plan for the Great Barrier Reef World Heritage Area: 1994-2019. Great Barrier Reef Marine Park Authority, Townsville, Australia. [online] URL: http://www.gbrmpa.gov.au/ data/assets/pdf file/0004/5476/the-25-year-strategic-plan-1994. pdf.

Great Barrier Reef Marine Park Authority (GBRMPA). 2009. Great Barrier Reef outlook report 2009. Great Barrier Reef Marine Park Authority, Townsville, Australia. [online] URL: http://www. gbrmpa.gov.au/_data/assets/pdf_file/0018/3843/OutlookReport_Full. pdf.

Great Barrier Reef Marine Park Authority (GBRMPA). 2014. Great Barrier Reef outlook report 2014. Great Barrier Reef Marine Park Authority, Townsville, Australia.

Gelcich, S., T. P. Hughes, P. Olsson, C. Folke, O. Defeo, M. Fernández, S. Foale, L. H. Gunderson, C. Rodríguez-Sickert, and M. Scheffer. 2010. Navigating transformations in governance of Chilean marine coastal resources. Proceedings of the National Academy of Sciences 107:16794-16799. http://dx.doi.org/10.1073/ pnas. 1012021107

Gunn, J., G. Fraser, and B. Kimball. 2010. Review of the Great Barrier Reef Marine Park structural adjustment package. Australian Government, Department of the Environment, Canberra, Australia. [online] URL: http://www.environment.gov. au/system/files/resources/4b3d907c-a200-40ce-88b0-c377c371357f/ files/gbrmp-sap-review.pdf.

Harrison, H. B., D. H. Williamson, R. D. Evans, G. R. Almany, S. R. Thorrold, G. R. Russ, K. A. Feldheim, L. van Herwerden, S. Planes, M. Srinivasan, M. L. Berumen, and G. P. Jones. 2012. Larval export from marine reserves and the recruitment benefit for fish and fisheries. Current Biology 22(11):1023-1028. http:// dx.doi.org/10.1016/j.cub.2012.04.008

Hughes, T. P., D. R. Bellwood, A. H. Baird, J. Brodie, J. F. Bruno, and J. M. Pandolfi. 2011. Shifting base-lines, declining coral cover, and the erosion of reef resilience: comment on Sweatman et al.
(2011). Coral Reefs 30(3):653-660. http://dx.doi.org/10.1007/ s00338-011-0787-6

Kinzig, A. P., P. R. Ehrlich, L. J. Alston, K. Arrow, S. Barrett, T. G. Buchman, G. C. Daily, B. Levin, S. Levin, M. Oppenheimer, E. Ostrom, and D. Saari. 2013. Social norms and global environmental challenges: the complex interaction of behaviors, values, and policy. BioScience 63(3):164-175. http://dx.doi. org/10.1525/bio.2013.63.3.5

Leslie, H. M., X. Basurto, M. Nenadovic, L. Sievanen, K. C. Cavanaugh, J. J. Cota-Nieto, B. E. Erisman, E. Finkbeiner, G. Hinojosa-Arango, M. Moreno-Báez, S. Nagavarapu, S. M. W. Reddy, A. Sánchez-Rodríguez, K. Siegel, J. J. UlibarriaValenzuela, A. H. Weaver, and O. Aburto-Oropeza. 2015. Operationalizing the social-ecological systems framework to assess sustainability. Proceedings of the National Academy of Sciences 112(19):5979-5984. http://dx.doi.org/10.1073/pnas.1414640112

Lester, S. E., B. S. Halpern, K. Grorud-Colvert, J. Lubchenco, B. I. Ruttenberg, S. D. Gaines, S. Airamé, and R. R. Warner. 2009. Biological effects within no-take marine reserves: a global synthesis. Marine Ecology Progress Series 384:33-46. http://dx. doi.org/10.3354/meps08029

Macintosh, A., T. Bonyhady, and D. Wilkinson. 2010. Dealing with interests displaced by marine protected areas: a case study on the Great Barrier Reef Marine Park Structural Adjustment Package. Ocean and Coastal Management 53(9):581-588. http:// dx.doi.org/10.1016/j.ocecoaman.2010.06.012

Marschke, M., D. Armitage, L. Van An, T. Van Tuyen, and H. Mallee. 2012. Do collective property rights make sense? Insights from central Vietnam. International Journal of the Commons 6 (1):1-27. [online] URL: http://www.thecommonsjournal.org/ index.php/ijc/article/view/334.

Marton-Lefèvre, J. 2014. Planet at the crossroads. Science 346:525. http://dx.doi.org/10.1126/science.1261787

Mascia, M. B., and C. A. Claus. 2009. A property rights approach to understanding human displacement from protected areas: the case of marine protected areas. Conservation Biology 23(1):16-23. http://dx.doi.org/10.1111/j.1523-1739.2008.01050.x

Mascia, M. B., C. A. Claus, and R. Naidoo. 2010. Impacts of marine protected areas on fishing communities. Conservation Biology 24(5):1424-1429. http://dx.doi.org/10.1111/j.1523-1739.2010.01523. $\underline{\mathrm{X}}$

McCay, B. J. 1996. Common and private concerns. Pages 111-126 in S. Hanna, C. Folke, and K. G. Maler, editors. Rights to nature: ecological, economic, cultural and political principles of institutions for the environment. Island Press, Washington, D.C., USA.

McCay, B. J. 2002. Emergence of institutions for the commons: contexts, situations, and events. Pages 361-402 in E. Ostrom, T. Dietz, N. Dolsak, P. C. Stern, S. Stonich, and E. U. Weber, editors. The drama of the commons. National Academy Press, Washington, D.C., USA.

McCook, L. J., T. Ayling, M. Cappo, J. H. Choat, R. D. Evans, D. M. De Freitas, M. Heupel, T. P. Hughes, G. P. Jones, B. Mapstone, H. Marsh, M. Mills, F. J. Molloy, C. R. Pitcher, R. L. Pressey, G. R. Russ, S. Sutton, H. Sweatman, R. Tobin, D. R. 
Wachenfeld, and D. H. Williamson. 2010. Adaptive management of the Great Barrier Reef: a globally significant demonstration of the benefits of networks of marine reserves. Proceedings of the National Academy of Sciences 107(43):18278-18285. http://dx. doi.org/10.1073/pnas.0909335107

McCulloch, M., S. Fallon, T. Wyndham, E. Hendy, J. Lough, and D. Barnes. 2003. Coral record of increased sediment flux to the inner Great Barrier Reef since European settlement. Nature 421:727-730. http://dx.doi.org/10.1038/nature01361

McGinnis, M. D. 2011. An introduction to IAD and the language of the Ostrom Workshop: a simple guide to a complex framework. Policy Studies Journal 39(1):169-183. http://dx.doi.org/10.1111/ j.1541-0072.2010.00401.x

McGinnis, M. D., and E. Ostrom. 2014. Social-ecological system framework: initial changes and continuing challenges. Ecology and Society 19(2):30. http://dx.doi.org/10.5751/ES-06387-190230

Millennium Ecosystem Assessment 2005. Ecosystems and human well-being: synthesis. Island Press, Washington, D.C., USA. http://www.millenniumassessment.org/documents/document.356. aspx.pdf.

National Environmental Research Program. 2013. Project 10.2: socio-economic systems and reef resilience. National Environmental Research Program, Townsville, Australia. [online] URL: http:// www.nerptropical.edu.au/project/socio-economic-systems-and-reefresilience.

Olsson, P., C. Folke, and T. P. Hughes. 2008. Navigating the transition to ecosystem-based management of the Great Barrier Reef, Australia. Proceedings of the National Academy of Sciences 105(28):9489-9494. http://dx.doi.org/10.1073/pnas.0706905105

Ostrom, E. 1990. Governing the commons: the evolution of institutions for collective action. Cambridge University Press, Cambridge, UK.

Ostrom, E. 2003. How types of goods and property rights jointly affect collective action. Journal of Theoretical Politics 15 (3):239-270. http://dx.doi.org/10.1177/0951692803015003002

Ostrom, E. 2007. A diagnostic approach for going beyond panaceas. Proceedings of the National Academy of Sciences 104 (39):15181-15187. http://dx.doi.org/10.1073/pnas.0702288104

Ostrom, E. 2009. A general framework for analyzing sustainability of social-ecological systems. Science 325:419-422. http://dx.doi.org/10.1126/science. 1172133

Ostrom, V., and E. Ostrom 1977. Public goods and public choices. Pages 7-49 in E. S. Savas, editor. Alternatives for delivering public services: toward improved performance. Westview Press, Boulder, Colorado, USA.

Pinkerton, E., and D. N. Edwards. 2009. The elephant in the room: the hidden costs of leasing individual transferable fishing quotas. Marine Policy 33(4):707-713. http://dx.doi.org/10.1016/j. marpol.2009.02.004

Pollnac, R., P. Christie, J. E. Cinner, T. Dalton, T. M. Daw, G. E. Forrester, N. A. J. Graham, and T. R. McClanahan. 2010. Marine reserves as linked social-ecological systems. Proceedings of the National Academy of Sciences 107(43):18262-18265. http://dx. doi.org/10.1073/pnas.0908266107
Russ, G. R., and A. C. Alcala. 2011. Enhanced biodiversity beyond marine reserve boundaries: the cup spillith over. Ecological Applications 21(1):241-250. http://dx.doi.org/10.1890/09-1197.1

Russ, G. R., A. J. Cheal, A. M. Dolman, M. J. Emslie, R. D. Evans, I. Miller, H. Sweatman, and D. H. Williamson. 2008. Rapid increase in fish numbers follows creation of world's largest marine reserve network. Current Biology 18(12):R514-R515. http://dx. doi.org/10.1016/j.cub.2008.04.016

Schlager, E., and E. Ostrom. 1992. Property-rights regimes and natural resources: a conceptual analysis. Land Economics 68 (3):249-262. http://dx.doi.org/10.2307/3146375

Smith, M. D., J. Lynham, J. N. Sanchirico, and J. A. Wilson. 2010. Political economy of marine reserves: understanding the role of opportunity costs. Proceedings of the National Academy of Sciences 107(43)18300-18305. http://dx.doi.org/10.1073/pnas.0907365107

Stoeckl, N., C. C. Hicks, M. Mills, K. Fabricius, M. Esparon, F. Kroon, K. Kaur, and R. Costanza. 2011. The economic value of ecosystem services in the Great Barrier Reef: our state of knowledge. Annals of the New York Academy of Sciences 1219:113-133. http://dx.doi.org/10.1111/j.1749-6632.2010.05892. $\underline{x}$

Sweatman, H. 2008. No-take reserves protect coral reefs from predatory starfish. Current Biology 18(14):R598-R599. http://dx. doi.org/10.1016/j.cub.2008.05.033

Sweatman, H., S. Delean, and C. Syms. 2011. Assessing loss of coral cover on Australia's Great Barrier Reef over two decades, with implications for longer-term trends. Coral Reefs 30 (2):521-531. http://dx.doi.org/10.1007/s00338-010-0715-1

Toropova, C., I. Meliane, D. Laffoley, E. Matthews, and M. Spalding, editors. 2010. Global ocean protection: present status and future possibilities. International Union for Conservation of Nature and Natural Resources, Gland, Switzerland. [online] URL: https://portals.iucn.org/library/efiles/documents/2010-053. pdf.

United Nations Educational, Scientific, and Cultural Organization (UNESCO). 2012. Convention concerning the protection of the world cultural and natural heritage. 36th session. UNESCO, Paris, France. [online] URL: http://whc.unesco.org/ archive/2012/whc12-36com-7BAdd-en.pdf.

Vincent, A. C. J., and J. M. Harris. 2014. Boundless no more. Science 346:420-421. http://dx.doi.org/10.1126/science.1255923

Watling, L., and E. A. Norse. 1998. Disturbance of the seabed by mobile fishing gear: a comparison to forest clearcutting. Conservation Biology 12(6):1180-1197. http://dx.doi.org/10.1046/ j.1523-1739.1998.0120061180.x

Williamson, D. H., G. R. Russ, and A. M. Ayling. 2004. No-take marine reserves increase abundance and biomass of reef fish on inshore fringing reefs of the Great Barrier Reef. Environmental Conservation 31(2):149-159. http://dx.doi.org/10.1017/ S0376892904001262

Worm, B., E. B. Barbier, N. Beaumont, J. E. Duffy, C. Folke, B. S. Halpern, J. B. C. Jackson, H. K. Lotze, F. Micheli, S. R. Palumbi, E. Sala, K. A. Selkoe, J. J. Stachowicz, and R. Watson. 2006. Impacts of biodiversity loss on ocean ecosystem services. Science 314:787-790. http://dx.doi.org/10.1126/science.1132294 
Yandle, T. 2006. Property rights and ocean governance. Science 314:593-595. http://dx.doi.org/10.1126/science.314.5799.593

Yin, R. K. 1984. Case study research: design and methods. Fourth edition. Sage, Thousand Oaks, California, USA. 